\title{
Antioxidant activities of Rhus verniciflua seed extract and quality characteristics of fermented milk containing Rhus verniciflua seed extract
}

\author{
Hee-Yeon Jin, Yu-Jin Choi, Hye-Jung Moon, Jae-Hee Jeong, Joong-Hyun Nam, \\ Sang-Cheon Lee, Chang-Ki Huh* \\ Imsil Research Institute of Cheese Science, Imsil 55918, Korea
}

\section{옻씨 추출물의 항산화 활성과 옻씨 추출물을 첨가한 발효유의 품질특성}

\author{
진희연 · 최유진 · 문혜정 · 정재희 · 남중현 · 이상천 · 허창기* \\ (재)임실치즈과학연구소
}

\begin{abstract}
This study was carried out to investigate the quality characteristics of fermented milk containing Rhus verniciflua seed (RVS) extracts $(0.0 \%, 0.1 \%, 0.3 \%$ and $0.5 \%)$ and antioxidant activity of RVS extracts. The proximate composition of RVS was moisture $(4.76 \%)$, crude ash $(1.40 \%)$, crude fat $(5.33 \%)$ and crude protein $(11.10 \%)$. A total polyphenol content of $70 \%$ ethanol extract of RVS $(554 \pm 2.64 \mathrm{mg} / \mathrm{g})$ was higher than that of RVS water extract $(145 \pm 3.47$ $\mathrm{mg} / \mathrm{g}) .70 \%$ ethanol extract $(1103 \pm 6.42 \mathrm{mg} / \mathrm{g})$ of RVS showed higher content in the total flavonoids $(37 \pm 2.30 \mathrm{mg} / \mathrm{g})$ and activities on DPPH free radical scavenging $(\mathbf{7 3 . 2 3} \%)$ and ABTS free radical scavenging $(\mathbf{8 3 . 4 7 \%})$ when compared with water extracted of RVS. The quality characteristics, such as $\mathrm{pH}$, titratable acidity, and the number of lactic acid producing bacteria were not remarkably different between the fermented milk samples subjected to treatments with and without the addition of RVS extracts.
\end{abstract}

Key words : Rhus verniciflua seed extract, urushiol, physiological activities, fermented milk, quality characteristics

\section{서 론}

국내 발효음료 시장규모는 2011년 1조 6천억원으로 전체 음료시장의 $40 \%$ 를 차지하고 있으며 이 중 발효유 시장은 전체 음료시장의 $81 \%$ 를 차지하고 있다(1). 발효유를 통하 여 섭취되는 유산균은 장내로 유입된 후 장내 상피세포에 착생하게 되어 면역 활성 증진, 병원성 미생물의 증식저해, 발암 원인 효소 생성억제 및 암 발생률의 감소 등 사람의 인체기능에 유익한 효과를 발휘한다(2). 유산균은 직접 또 는 간접적으로 식품에 이용되어 왔으며, 유산균을 이용한

*Corresponding author. E-mail : moonerhuh@irics.re.kr Phone : 82-63-644-2181, Fax : 82-63-644-2186

Received 5 August 2016; Revised 13 September 2016; Accepted 21 September 2016.

Copyright (c) The Korean Society of Food Preservation. All rights reserved.
식품은 대사산물인 유산에 의하여 저장성이 향상되고, 식 품의 향미 부여와 조직 개선의 기능이 있고, 유산균에 의한 발효는 식품의 영양 및 기능성 증가 등의 작용을 한다(3). 또한, 최근에는 인삼, 홍삼추출액, 녹차, 복분자즙, 알로에, 매실 등을 첨가한 발효유가 많이 출시되고 있으며, 이들 제품은 기능성뿐만 아니라 기호도 증진에도 기여하고 있다 (4-6).

옻나무(Rhus verniciflua stokes)는 한국, 중국, 일본 등 아시아 지역에서 대부분 생산되고, 한국의 옻나무 재배지 역은 대부분 충북 옥천군과 강원도 원주시에 생산되고 있었 으나, 최근 전북 임실군도 옻나무 재배단지를 조성하여 지 역전략작목으로 육성 중에 있다. 국내 옻나무 생산면적은 2002년 1,216천 $\mathrm{m}^{2}$ 에서 2007년 3,058천 $\mathrm{m}^{2}$ 으로 증가하였 고, 옻의 식용판매 비중도 $52.5 \%$ 에서 $75.8 \%$ 로 증가하였다 (7).

옻은 항산화, 항염증, 항종양 등 다양한 생리활성이 있는 
것으로 알려지면서 건강기능성 식품 및 의약품 소재로 주목 받고 있다(8,9). 하지만 옻나무 유래의 urushiol은 수포, 가려 움, 발진 등 피부염과 알레르기를 유발하므로 옻나무의 식 품으로의 사용은 제한되어 있다(10). 식품의약품안전처에 서는 알레르기 유발성분인 urushiol을 포함하지 않는 옻 추출물을 옻닭 조리용에 한정하여 제한적으로 사용하도록 하고 있다(11). 이처럼 다양한 기능성을 갖고 있지만, urushiol 로 인해 제한적으로 사용되고 있는 옻나무의 활용 가치를 높일 수 있는 다양한 연구가 필요한 상황이다. 옻나 무의 활용 가치를 높일 수 있는 옻씨를 활용하는 방안이 있다.

옻씨의 겉껍질은 섬유질로서 면섬유로 쌓여져 있고, 외 피 $\rightarrow$ 중간피 $\rightarrow$ 밀납층 $\rightarrow$ 배아 순으로 층을 이루고 있다. 형태 는 둥근 납작 하며, 재배 농가에서는 옻씨차 및 옻씨 기름으 로 소량 이용하고 있는 실정이나, 사업화를 위한 과학적인 기초자료 및 제품 개발 연구들은 전무한 상황이다. 이에 반해 일본에서는 옻씨의 과학적인 기초자료를 근거로 옻씨 차를 생산해 시중에 판매가 되고 있으며 선호하는 차의 한 종류이기도 하다(12). 따라서 본 연구에서는 옻씨의 일반 성분과 urushiol 함량 및 항산화 활성 측정을 통한 옻씨 활용의 기초자료를 제공하고, 또한 옻씨 추출물이 첨가된 발효유의 품질 특성을 파악해 유제품 개발을 목적으로 하였다.

\section{재료 및 방법}

\section{실험재료}

본 실험에 사용된 옻씨는 전북 임실군 농업법인 임실참 옻세상(주)에서 2014년 수확된 원료를 구입하여 이물질을 제거하고 분쇄하여 시료로 사용하였다. 원유는 임실지역의 홀스타인 프리지안(Holstein-Friesian)종에서 생산된 산도 가 $0.15 \%, \mathrm{pH}$ 는 6.8 인 신선한 원유를 사용하였다.

\section{시약 및 배지}

사용 용매인 Ethanol(HPLC용), Acetonitrile(HPLC용) 및 Methanol(HPLC용)은 J.T.Baker사(NJ, USA) 사용하였고, 표준물질인 Urushiol은 PhytoLab GmbH사(Vestenbergsgreuth, Germany), Quercetin과 Gallic acid는 Sigma - Aldrich사(St. Louis, MO, USA), Diethylene glycol, DPPH 용액 및 potassium persulfate는 Sigma-Aldrich사(St. Louis, MO, USA), Folin-Ciocalteu reagent는 Millipore사(Darmstadt, Germany) 것을 구입하여 사용하였고, BCP 배지는 Eiken chemical 사(Tokyo, Japan) 것을 구입하여 사용하였다.

\section{추출물 제조}

분쇄된 옻씨 시료의 10 배 중량의 물 또는 $70 \%$ 에탄올을 넣고 24 시간 동안 실온에서 3회 반복하여 추출한 뒤
$10,000 \times \mathrm{g}$ 원심분리 하였다. 조추출물은 Brix $1 \%$ 내외로 $60^{\circ} \mathrm{C}$ 감압농축 하였으며 유기물을 휘발시키고 동결건조 하였다. 동결건조 된 추출 수율은 1 3\% 로 옻씨 추출물은 냉장 보관하면서 실험에 사용하였다.

\section{일반성분 분석}

옻씨의 일반성분 함량은 $\mathrm{AOAC}$ 표준분석법(13)에 따라 실시하였다. 수분은 $105^{\circ} \mathrm{C}$ 상압가열건조법, 회분은 $550^{\circ} \mathrm{C}$ 회화처리, 조단백질의 함량은 Kjeldahl법, 조지방은 Soxhlet 추출법으로 측정하였다. 탄수화물 함량은 $100 \%$-(단백질+ 지방+회분+수분)으로 나타내었다.

\section{Urushiol 분석}

Urushiol 분석은 공인시험기관인 한국과학기술연구원 특성분석센터에 의뢰하여 분석하였다. 옻씨 및 옻씨 추출 물 $1 \mathrm{~g}$ 에 $\mathrm{CHCl}_{3}$ 용액 $5 \mathrm{~mL}$ 첨가해 30 분간 초음파 추출한 후 조추출물을 모아 $0.45 \mathrm{Mm}$ 여과하여 분석용 시료로 사용 하였다. 분석은 HPLC(Alliance e2695, Waters Co., Milford, MA, USA)를 이용하였다. 컬럼은 YMC Pack Pro $\mathrm{C}_{18} \mathrm{RS}$ (ID4.6×250 mm, YMC Co., Toyoto, Japan)를 사용하였고, 컬럼 오븐의 온도는 $40^{\circ} \mathrm{C}$, 유속은 $1.0 \mathrm{~mL} / \mathrm{min}$ 으로 하였다. 이동상은 $0.1 \%$ TFA in $\mathrm{H}_{2} \mathrm{O} 15 \%$ 와 $\mathrm{CH}_{3} \mathrm{CN} 85 \%$ 를 사용하였 으며, 검출기의 파장은 $260 \mathrm{~nm}$ 로 하였다. Urushiol(15:3) standard는 $\mathrm{CHCI}_{3}$ 으로 희석하여 사용하였다.

\section{총 플라보노이드 분석}

옻씨 추출물 $1 \mathrm{~mL}$ 와 diethylene glycol $10 \mathrm{~mL}$ 를 혼합하고 $1 \mathrm{~N} \mathrm{NaOH}$ 용액 $1 \mathrm{~mL}$ 을 가하여 1 시간 반응시킨 후, 420 $\mathrm{nm}$ 에서 흡광도를 측정하였다(14). 분석은 각 시료당 3 반복 실시하였고, 이 때 표준물질은 quercetin을 사용하여 표준검 량 곡선을 작성한 다음 총 플라보노이드 함량을 구하였다.

\section{총 폴리페놀 분석}

총 폴리페놀은 Folin-Ciocaltus 발색법(15)에 준해 분석하 였다. 옻씨 추출물 $1 \mathrm{~mL}$ 에 증류수 $7.5 \mathrm{~mL}$ 을 가한 후 3 분간 방치시킨 다음 Folin-Ciocalteu reagent $0.5 \mathrm{~mL}$ 를 첨가 하고 $3.5 \%$ sodium carbonate anhydrous $1 \mathrm{~mL}$ 을 넣은 후 1 시간 동안 방치 후, $760 \mathrm{~nm}$ 에서 흡광도를 측정하였다. 표준물질 은 gallic acid을 사용하여 표준검량 곡선을 작성 후 총 폴리 페놀 함량을 정량하였다.

$\mathrm{DPPH}$ (1,1-diphenyl-2-picryhydrazyl) 자유 라디칼 소거활성 측정

DPPH radical 소거활성은 Blois의 방법(16)을 변형하여 측정하였다. 각 추출물을 농도별로 녹인 후, 메탄올에 용해 시킨 $0.1 \mathrm{mM} \mathrm{DPPH}$ 용액 $150 \mathrm{uL}$ 와 추출물 $50 \mathrm{uL}$ 을 혼합하 여 30 분간 암소에서 반응시킨 후 $530 \mathrm{~nm}$ 에서 흡광도를 
측정하였다.

ABTS (2-2'-azino-bis3-ethylbenzothiazoline-6sulphonic acid) 자유 라디칼 소거활성 측정

$\mathrm{ABTS}$ 라디칼을 이용한 항산화 활성 측정은 potassium persulfate의 반응에 의해 생성된 $\mathrm{ABTS}$ 라디칼이 추출물 내의 항산화 물질에 의해 제거되어 청록색으로 탈색되는 것을 이용한 방법(17)이다. $2.4 \mathrm{mM}$ potassium persulfate 용 액을 $7 \mathrm{mM} \mathrm{ABTS}$ 가 되도록 용해시킨 다음 암소에서 24시 간 동안 반응 시켰다. ABTS solution을 형성 시킨 후 630 $\mathrm{nm}$ 에서 흡광도 값이 $0.70 \pm 0.02$ 가 되게 증류수로 희석하였 다. 희석된 용액과 각 추출물을 1:1로 혼합 한 후 $630 \mathrm{~nm}$ 에서 흡광도를 측정하였다.

\section{옻씨 추출물을 첨가한 발효유 제조}

원유에 $5 \%$ 설탕과 옻씨의 항산화 활성이 높게 나타난 에탄올 추출물을 $0.0 \%, 0.1 \%, 0.3 \%, 0.5 \%$ 첨가한 후, $90^{\circ} \mathrm{C}$ 에 서 10 분간 살균하고 냉각하였다. 종균 배양을 위해 FD-DVS YF-L812 $0.03 \%$ 를 접종하고 $37^{\circ} \mathrm{C}$ 에서 배양하면서 품질 변 화를 확인하였다. 옻씨 추출물이 첨가된 발효유 제조공정 은 Fig. 1 과 같다.

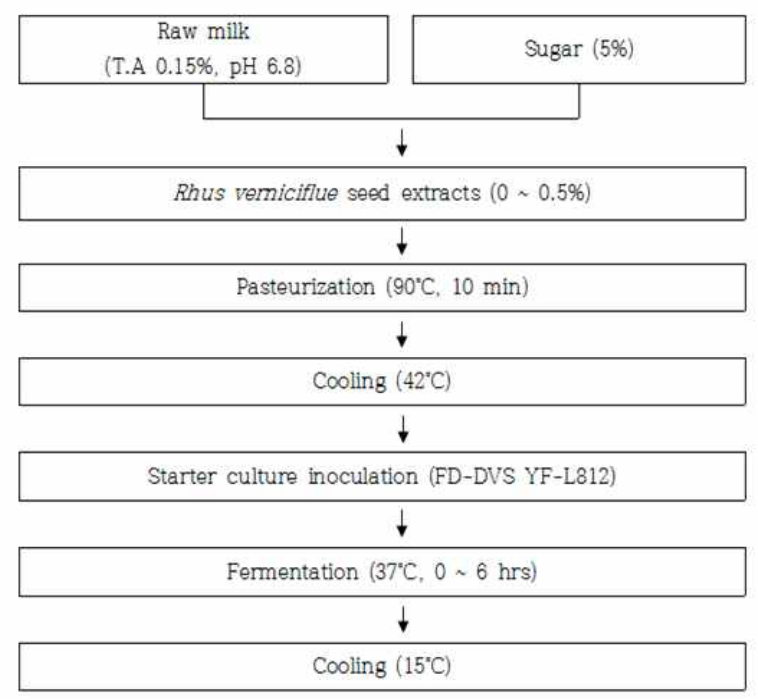

Fig. 1. Procedures for the manufacture methods of fermented milk with the Rhus verniciflua seed extracts.

발효유 제조과정 중 품질변화 측정

옻씨 에탄올 추출물을 첨가한 발효유의 제조 과정 중 $\mathrm{pH}$ 는 $\mathrm{pH}$ meter(UB-10, Denver, USA)를 이용하여 측정하였 고, 적정산도는 채취한 시료를 10 배 희석한 후 $0.1 \mathrm{~N} \mathrm{NaOH}$ 를 첨가하여 $\mathrm{pH}$ 가 $\mathrm{pH}$ 8.3이 도달하기 까지 용량을 기록하 고, 이를 전환계수인 0.9 를 곱한 후 검체의 무게 $(\mathrm{g})$ 를 나누어 나타낸 값을 적정산도(\%)로 하였다. 유산균수의 변화는 시 료 $1 \mathrm{~mL}$ 채취하여 멸균수에 십진 희석하여 유산균 배지
$\mathrm{BCP}$ 에 접종한 후 Standard Plate Count법으로 $37^{\circ} \mathrm{C}$ 에서 48 시간 배양 후 형성된 colony 수를 측정하여 시료 $1 \mathrm{~mL}$ 중의 $\mathrm{CFU}$ (colony forming unit)로 나타냈다.

\section{결과 및 고찰}

\section{일반성분}

옻씨의 일반성분 함량은 Table 1 과 같다. 옻씨의 수분은 $4.76 \pm 0.28 \%$, 조단백질은 $11.10 \pm 0.67 \%$, 조지방은 $5.33 \pm$ $0.58 \%$, 조회분은 $1.40 \pm 0.07 \%$, 탄수화물은 $77.41 \%$ 의 함량 을 보였다. 옻나무의 성분을 분석한 Choi 등(18)에 의하면 옻나무의 탄수화물은 수피 $77.15 \%$, 목질부 $85.24 \%$ 를 함유 한 것으로 나타났다. 이로써 옻의 수피, 목질 및 씨 모두에서 탄수화물 비율이 가장 높은 것으로 나타났으며, 이는 구성 성분의 대부분이 lignin, cellulose, hemicellulose 등이 차지 하고 있기 때문이다. Jang 등(19)에 의하면 홍화씨의 수분함 량은 $5.58 \%$, 조단백질 함량은 $37.16 \%$, 조지방 함량은 $13.69 \%$, 조회분 함량은 $3.52 \%$ 로 보고하였고, 탄수화물 함 량은 $40 \%$ 로 옻씨에 비해 적었다.

Table 1. Proximate composition of Rhus verniciflua seed (\%)

\begin{tabular}{cc}
\hline Proximate composition & Rhus verniciflua seed \\
\hline Moisture & $4.76 \pm 0.28$ \\
Crude protein & $11.10 \pm 0.67$ \\
Crude fat & $5.33 \pm 0.58$ \\
Crude ash & $1.40 \pm 0.07$ \\
Carbohydrate & 77.41 \\
\hline
\end{tabular}

\section{Urushiol}

Urushiol은 옻나무 껍질에서 나오는 옻의 주성분으로 '옻 으름' 이라는 피부염을 일으키는 알레르기 유발 항원이다. Park 등(20)의 연구 결과에서 보면 산지별 옻나무 껍질의 urushiol 함량은 함양산 $4.59 \mathrm{mg} / \mathrm{g}$, 원주산 $4.50 \mathrm{mg} / \mathrm{g}$ 이라고 보고하였다. 옻나무의 경우 다양한 기능성을 함유 하고 있 지만, urushiol의 알레르기 유발 항원으로 인해 제한적으로 사용 되어 지고 있는 상황이다. 따라서 옻씨 또한 urushiol 함유 유무를 확인한 결과는 Fig. 2와 같다. Urushiol 표준품 의 크로마토그램과 비교해 옻씨, 껍질을 탈피한 옻씨, 물 추출물 및 $70 \%$ 에탄올 추출물의 모두 urushiol 성분이 검출 되지 않았다. 따라서 옻씨의 경우 다양한 기능성을 갖고 있지만 식품으로써의 활용 범위가 떨어지는 옻나무에 비해 다양한 활용성과 가치가 본 연구에서 확인되었다.

\section{총 플라보노이드 및 총 폴리페놀}

식품 속 생리활성물질 중 페놀류는 강한 항산화 활성을 가지고 있는 것으로 알려져 있으며, 다양한 기능성에 대한 


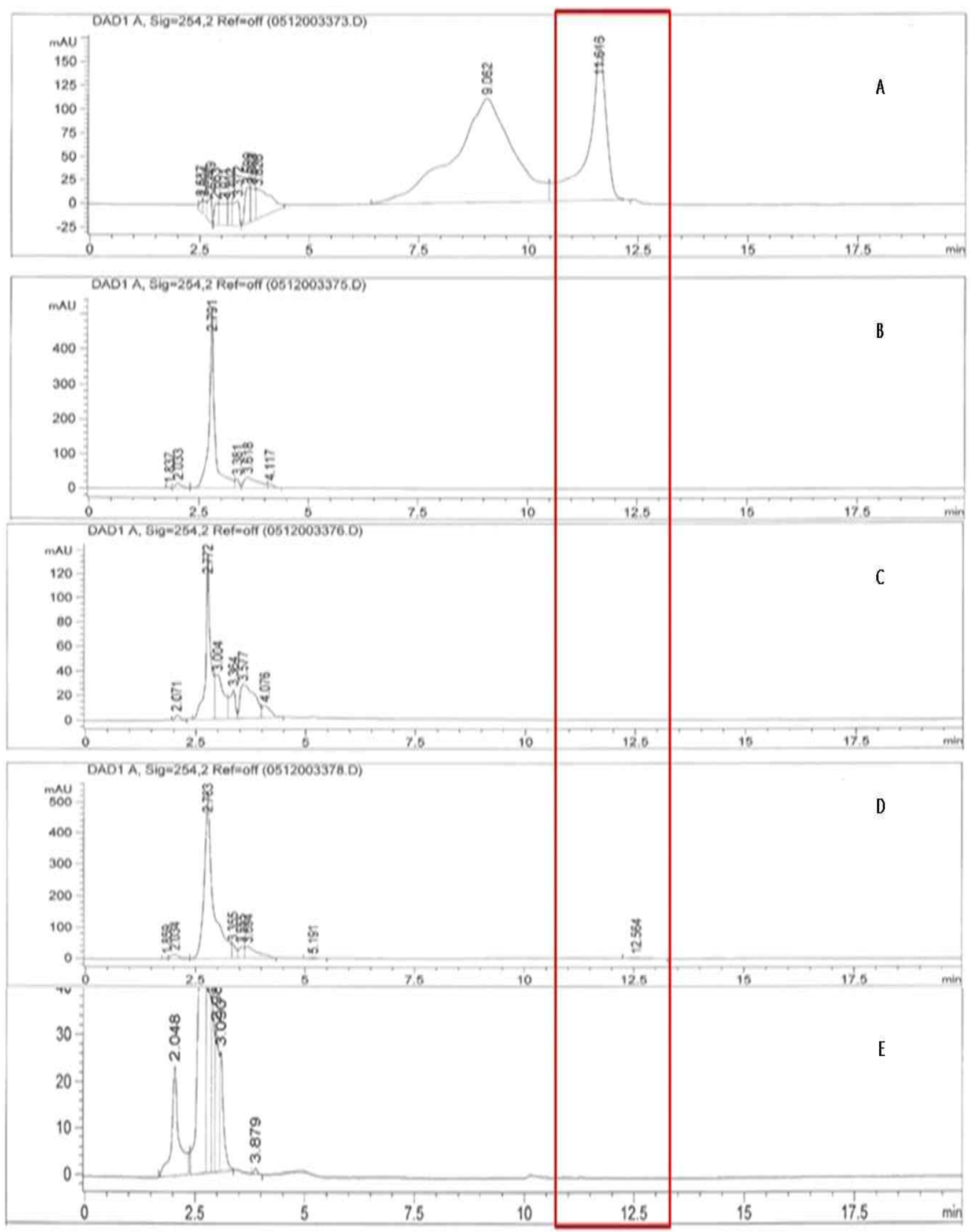

Fig. 2. Comparison of urushiol chromatogram between distilled water and $70 \%$ EtOH extract from Rhus verniciflua seed. A, Standard; B, Seed; C, Seed+Peel; D, 70\% Ethanol Extract; E, DW Extract. 
연구가 진행되고 있다(21). 옻씨의 총 플라보노이드 및 총 폴리페놀 함량을 분석한 결과는 Table 2에서 보는 바와 같다. 물 추출물의 총 폴리페놀 및 총 플라보노이드 함량은 $145 \pm 3.47 \mathrm{mg} \mathrm{GAE} / \mathrm{g}$ 및 $37 \pm 2.30 \mathrm{mg} \mathrm{QE} / \mathrm{g}$ 으로 나타났으며, 에탄올 추출물의 총 폴리페놀 및 총 플라보노이드 함량은 $554 \pm 2.64 \mathrm{mg} \mathrm{GAE} / \mathrm{g}$ 및 $1,103 \pm 6.42 \mathrm{mg} \mathrm{QE} / \mathrm{g}$ 으로 나타났다. $\mathrm{Kim}$ 등(22)은 홍화의 부위별 총 폴리페놀 함량을 측정한 결과 씨 추출물이 어린 싹, 잎, 꽃봉오리 부위에 비해서 다소 높았고, 총 플라보노이드 함량 또한 홍화씨 추출물이 가장 높게 나타났다고 보고하였다. 식품으로 사용가능한 추출용매(물, 주정)를 고려해 볼 때 옻씨 추출물 첨가 발효 유 제조시 항산화 활성이 높게 나타난 주정 추출물을 사용 하는 것이 바람직한 것으로 사료된다.

Table 2. Total polyphenols and total flavonoids contents of extract from Rhus verniciflua seed (RVS)

\begin{tabular}{ccc}
\hline & $\begin{array}{c}\text { Total polyphenols } \\
(\mathrm{mg} \mathrm{GAE} / \mathrm{g})\end{array}$ & $\begin{array}{c}\text { Total flavonoids } \\
(\mathrm{mg} \mathrm{QE} / \mathrm{g})\end{array}$ \\
\hline RVS D.W ex. & $145 \pm 3.47$ & $37 \pm 2.30$ \\
RVS 70\% EtOH ex. & $554 \pm 2.64$ & $1103 \pm 6.42$ \\
\hline
\end{tabular}

$\mathrm{DPPH}$ (1,1-diphenyl-2-picryhydrazyl) 자유 라디칼 소거활성 측정

$\mathrm{DPPH}$ 는 안정한 라디칼을 갖는 물질로 항산화 활성이 있는 물질과 반응하면 라디칼이 소거되어 탈색하는 점을 이용하여 다양한 천연소재로부터 항산화 활성을 검색하는 데 사용된다 $(23,24)$. 옻씨 추출물의 DPPH 라디칼 소거능 측정 결과는 Fig. 3과 같다. 물 추출물과 에탄올 추출물 모두 농도가 높을수록 라디칼 소거능이 높았고, 그 중 에탄 올 추출물이 물 추출물에 비해 높은 활성을 보여 유의적인 차이가 나타났다.

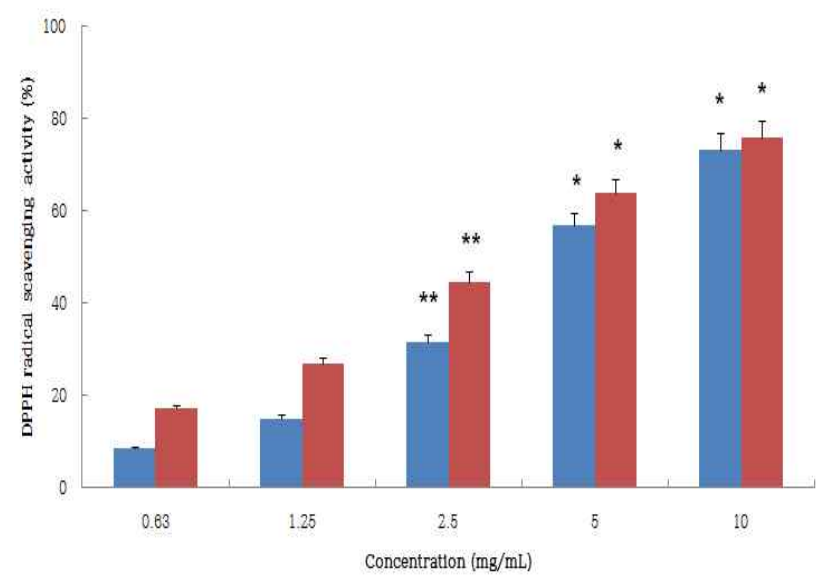

Fig. 3. DPPH radical scavenging activity (\%) of extract from Rhus verniciflua seed DW extraction and $70 \% \mathrm{EtOH}$ extraction. Values are presented mean \pm SD.
ABTS (2-2'-azino-bis3-ethylbenzothiazoline-6sulphonic acid) 자유 라디칼 소거활성 측정

$\mathrm{ABTS}$ 는 potassium persulfate와의 산화에 의해 라디칼을 형성시킨 후 각 시료에 대한 자유라디칼 소거능을 측정 하는 방법으로, $\mathrm{DPPH}$ 라디칼 소거능과 함께 항산화 활성 평가 항목으로 많이 사용되고 있다(25). 옻씨 추출물의 $\mathrm{ABTS}$ 라디칼 소거능은 Fig. 4와 같다. 물 추출물의 경우 농도가 높을수록 라디칼 소거능이 높아져 농도에 따른 유의 적 차이를 보였으며, 에탄올 추출물은 유의적인 차이를 보 이지 않았다. 위의 DPPH 라디칼 소거능 측정 결과 에탄올 추출물에서 활성이 높았으나, $\mathrm{ABTS}$ 라디칼 소거능 측정 결과는 물 추출물이 높게 나타나 차이를 보였다.

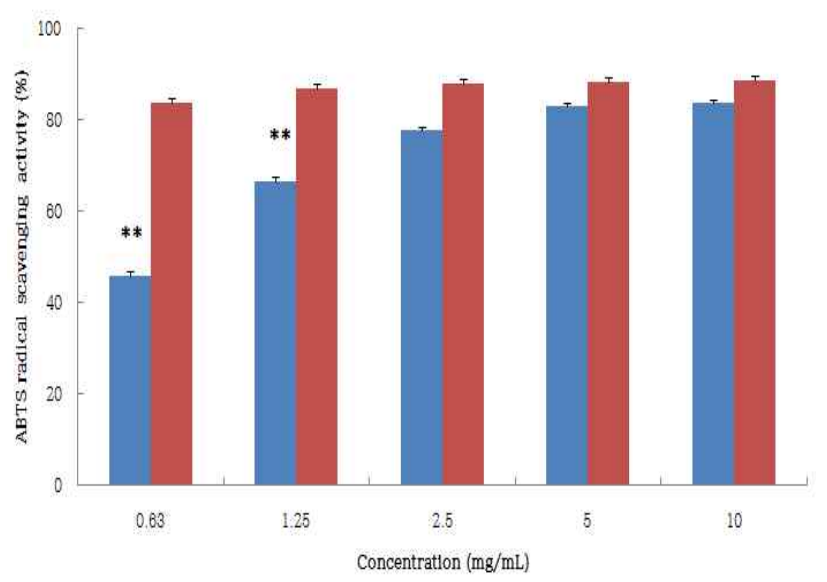

Fig. 4. ABTS radical scavenging activity (\%) of extract from Rhus verniciflua seed DW extraction and $70 \% \mathrm{EtOH}$ extraction.

Values are presented mean \pm SD.

\section{옻씨 발효유의 발효 적성}

옻씨 에탄올 추출물을 첨가한 발효유의 배양 시간에 따 른 $\mathrm{pH}$ 변화는 Fig. 5(A)와 같다. $\mathrm{pH}$ 변화는 배양 직후 $\mathrm{pH}$ 6.5 로 시작해서 배양이 진행됨에 따라 $\mathrm{pH}$ 가 급격히 낮아졌 으며, 발효 종료 시점인 6시간째 $\mathrm{pH} 4.4 \sim 4.5$ 에 도달하였다. 옻씨 에탄올 추출물이 첨가된 시료구의 경우 대조구에 비해 $\mathrm{pH}$ 저하 속도가 빨랐다. 현재 시판되고 있는 발효유의 $\mathrm{pH}$ 는 4.27 4.53이라고 알려져 있으며, 본 실험에서도 $\mathrm{pH} 4.3 \sim 4.5$ 정도로 비슷한 결과가 나타났다. 적정산도의 변화는 Fig. 5 (B)와 같다. 적정 산도의 경우 배양 직후 $0.13 \sim 0.14 \%$ 로 시작해서 배양이 진행됨에 따라 증가하는 경향을 보였고, 배양 3 시간 후 적정 산도가 급격이 증가하여 발효 종료 시점인 6시간째 $0.6 \%$ 함량을 나타났다. 적정 산도의 변화는 전반적으로 발효 과정에 따라 지속적으로 증가 하였으며, 발효 완료 후 TA가 $0.7 \%$ 에 도달하였다. 옻씨 에탄올 추출물 을 첨가한 발효유의 배양 시간에 따른 유산균수의 변화는 Fig. 5(C)와 같다. 유산균 수의 변화는 배양 직후 $4.0 \times$ $10^{6} \sim 4.2 \times 10^{6} \mathrm{CFU} / \mathrm{g}$ 로 시작해서 배양이 진행됨에 따라 유산 균 수는 증가하였으며, 3 시간 이후 급속히 증가하여 
$5.0 \times 10^{9} \sim 5.3 \times 10^{9} \mathrm{CFU} / \mathrm{g}$ 으로 나타났다. 대조구와 옻씨 에탄 올 추출물 모두 첨가 농도와 관계없이 발효 시간 경과에 따라 유산균수가 증가하였다.
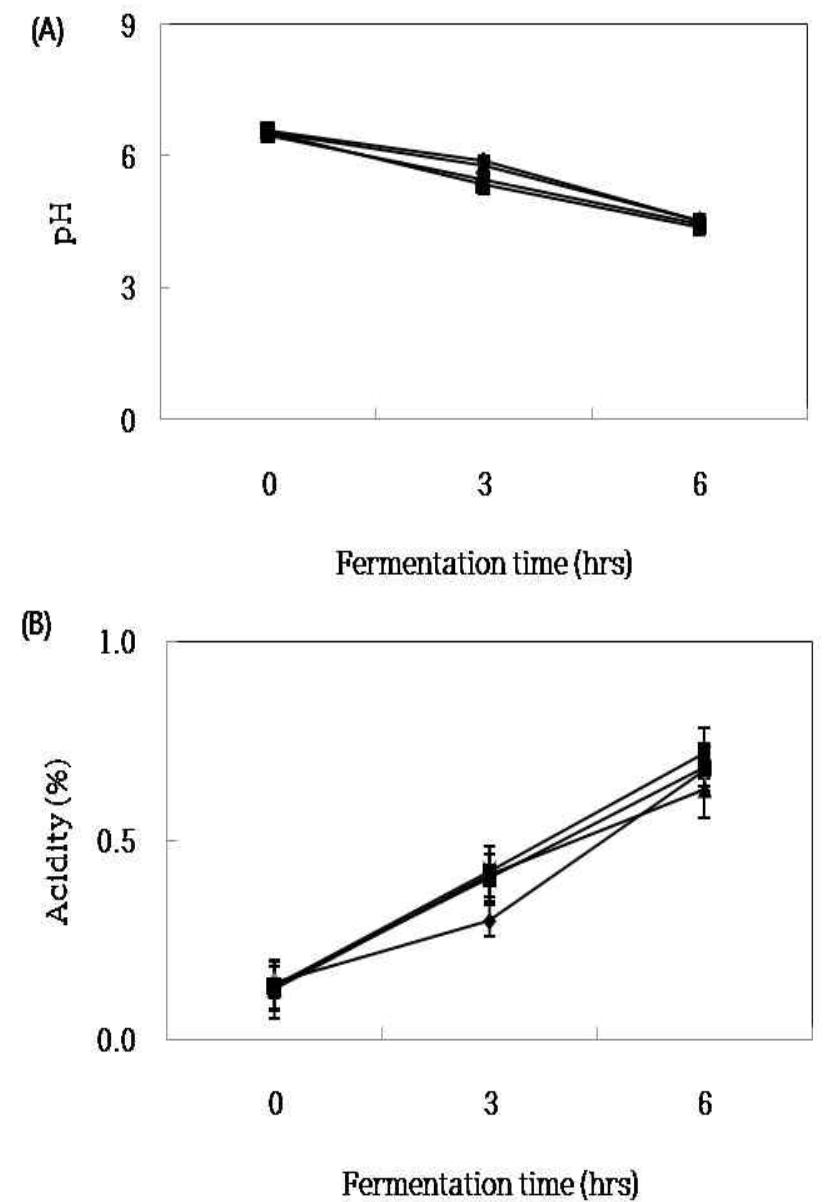

(C)

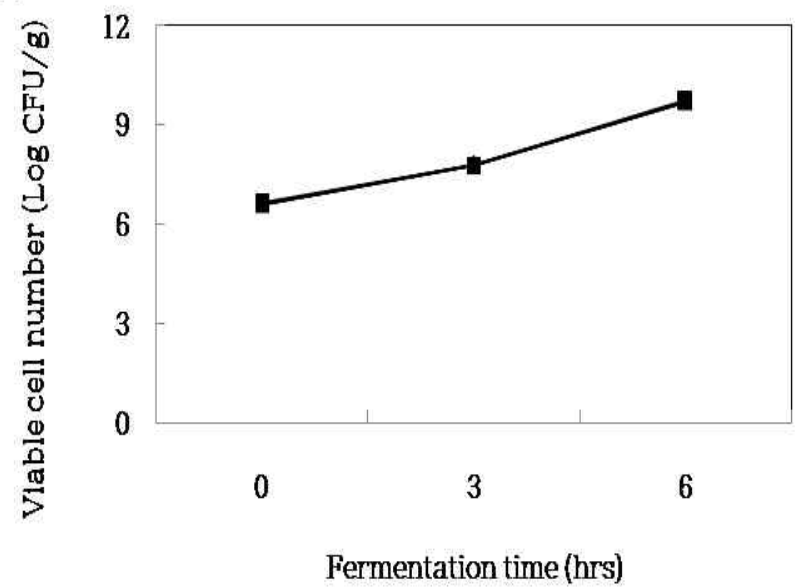

Fig. 5. Changes in the quality of fermented milk containing Rhus verniciflua seed ethanol extract (A) $\mathrm{pH}$, (B) titratable acidity, (C) viable cell counts.

, 0\%; , Fermentation milk added 0.1\% RVS extract; $\mathbf{\Delta}$, Fermentation milk added $0.3 \%$ RVS extract; $\times$, Fermentation milk added $0.5 \%$ RVS extract.

\section{요 약}

본 연구는 옻씨의 물과 에탄올 추출물의 항산화 활성을 평가하고, 옻씨 에탄올 추출물을 첨가한 발효유의 품질특 성에 대해 조사하였다. 옻씨의 수분은 $4.76 \pm 0.28 \%$, 조단백 질 $11.10 \pm 0.67 \%$, 조지방 $5.33 \pm 0.58 \%$, 조회분 $1.40 \pm 0.07 \%$ 및 탄수화물은 $77.41 \%$ 의 함량을 보였다. 총 폴리페놀 및 총 플라보노이드 함량은 물 추출물은 $145 \pm 3.47 \mathrm{mg} \mathrm{GAE} / \mathrm{g}$ 및 $37 \pm 2.30 \mathrm{mg} \mathrm{QE} / \mathrm{g}$ 으로 나타났으며, 에탄올 추출물의 총 폴리페놀 및 총 플라보노이드 함량은 $554 \pm 2.64 \mathrm{mg} \mathrm{GAE} / \mathrm{g}$ 및 $1103 \pm 6.42 \mathrm{mg} \mathrm{QE} / \mathrm{g}$ 으로 나타났다. 옻씨의 urushiol은 물 추출물과 에탄올 추출물 모두에서 urushiol 성분이 검출 되지 않았다. 옻씨의 DPPH 라디칼 소거활성은 각 추출물의 농도가 높을수록 라디칼 소거능이 높았고 추출물들 간의 유의적인 차이가 나타났다. ABTS 라디칼 소거활성은 물 추출물의 농도가 높을수록 라디칼 소거능이 높았고, 에탄 올 추출물은 농도에 따른 유의적 차이를 보이지 않았다. 옻씨 추출물을 첨가한 발효유의 배양 시간에 따른 $\mathrm{pH}$ 변화 는 배양이 진행됨에 따라 급격히 낮아져 $\mathrm{pH}$ 4.4 4.5로 나타 났고, 적정 산도는 발효 과정에 따라 지속적으로 증가하여 발효 완료 후 TA가 $0.7 \%$ 에 도달하였으며, 유산균수는 첨가 농도에 따른 차이를 보이지 않았다. 이상의 결과들을 종합 할 때, 옻씨를 첨가한 발효휴 제조시 옻씨 에탄올 추출물 첨가가 발효유의 품질변화에 큰 영향을 미치지 않음을 알 수 있었다.

\section{감사의 글}

본 연구는 농림축산식품부가 지원하는 2015년 농촌자원 복합산업화 지원사업 향토건강식품명품화사업으로 수행 된 연구결과 입니다.

\section{References}

1. Um IY, Kim SY, Jeon HJ (2012) Industry trend of fermented drinks. FACT, p 16

2. Leroy F, De Vuyst L (2004) Lactic acid bacteria as functional starter cultures for the food fermentation industry. J Korean Food Sci Technol, 15, 67-78

3. Jung YH, Choi HY, Bae IH (2011) Effects of Dandalion (Taraxacum mongolicum) powder on quality properties of yoghurt. Korean J Dairy Sci Technol, 29, 41-47

4. Ahn CS, Yeo JS, Bang IS (2009) Physicochemical characteristics of fermented milk containing mulberry leaf extract. Korean J Food \& Nutr, 22, 272-278 
5. Choi YJ, Yang HS, Huh CK, Oh HH, Park TY, Kim MK, Jin SW, Seo KS (2013) Quality characteristics and antioxidant activity of fermented milk containing mushroom extracts. Korean J Dairy Sci Technol, 31, 187-194

6. Bang BH, Park, HH (2000) Preparation of yogurt added with green tea and mugwort tea and quality characteristics. J Korean Soc Food Sci Nutr, 29, 854-859

7. KFS (2008) The investigation of forestry management of Korea. Korea Forest Service, Daejeon, Korea

8. Hong DH, Han SB, Lee CW, Park SH, Jeon YJ, Kim MJ, Kwak SS, Kim HM (2000) Cytotoxicity of urushiols isolated from sap of Korean lacquer tree Rhus vernicifera stokes. Arch Pharm Res, 22, 638-641

9. Choi HS, Kim BH, Yeo SH, Jeong ST, Choi JH, Park HS, Kim MK (2010) Physicochemical properties and physiological activities of Rhus verniciflua stem bark cultured with Fomitella fraxinea. Korean J Mycol, 38, $172-178$

10. Kim MO, Kim JS, Chun WJ, Kwon YS, Yu CY, Kim TY, Choi HS, Kim MJ (2009) Antioxidant activity and antimicrobial activity of stem bark of Rhus verniciflua stokes by fermentation. Korean J Medicinal Crop Sci, p 319-320

11. Park HJ, Yoon GM, Lee SH, Jang GY, Kim MY, Meishan L, Lee JS, Jeong HS (2013) Effects of extraction temperature and time on antioxidant activities of Rhus verniciflua extract. J Korean Soc Food Sci Nutr, 42, 1776-1782

12. Chio HS, Yeo SH, Jeong ST, Choi JH, Park HS, Kim MK (2012) Preparation and characterization of urushiol free fermented Rhus verniciflua stem bark (FRVSB) extracts. J Korean Food Sci Technol, 44, 173-178

13. AOAC (1995) Official methods of analysis. 16th ed. Association of official analytical chemists. Washington DC, USA

14. Lee JM, Son ES, OH SS, Han DS (2001) Contents of total flavonoid and biological activities of edible plants. Korean J Dietary culture, 16, 504-514

15. Dewanto V, Wu X, Adom KK, Liu RH (2002) Thermal processing enhances the nutritional value of tomatoes by increasing total antioxidant activity. J Agric Food Chem,
50, 3010-3014

16. Blois MS (1977) Antioxidant determinations by the use of a stable free radical. J Agric Food Chem, 25, 103-107

17. Re R, Pellegrini N, Proteggente A, Pannala A, Yang M, Rice-Evans C (1999) Antioxidant activity applying an improved abts radical cation decolorization assay. Free Radical Biol Med, 26, 1231-1237

18. Choi WS (2014) Effect of extraction conditions on anti-inflammatory activity and index compounds content in Rhus verniciflua stokes extract. MS Thesis, Chungbuk University, Korea, p 21

19. Jang JY (2013) Physicochemical characteristics of safflower seed (Carthamus tinctorius L.) and its biological activity. $\mathrm{Ph}$ D Thesis, Kongju University, Korea, p 30-31

20. Park SJ, Yang BW, Hahm YT, Oh DH, Kim JB, Yang JY, Kang BS (2012) Antioxidative activities of Rhus verniciflua bark from different area. Korean J Food \& Nutr, 25, 430-435

21. Jeong YJ, Yang YJ, Kang SC (2013) Constituent alterations of pueraiae radix and lacquer tree mixture extract and their anti-allergic effects. Korean J Plant Res, 26, 103-110

22. Kim HJ, Jun BS, Kim SK, Cha JY, Cho YS (2000) Polyphenolic compound content and antioxidative activities by extracts from seed, sprout and flower of safflower (Carthamus tinctorious L.). J Korean Soc Food Sci Nutr, 29, 1127-1132

23. Lee GO, You YH, Hwang KT, Lee JM, Lee HJ, Jun WJ (2012) Physicochemical characteristics and antioxidant activities of Luffa cylindrica (L.) Roem. J Korean Soc Food Sci Nutr, 41, 733-738

24. Lee SO, Kim MJ, Kim DG, Choi HJ (2005) Antioxidative activity of temperature- stepwise water extracts from Inonotus obliquus. J Korean Soc Food Sci Nutr, 34, 139-147

25. Jo YH, Park JW, Lee JM, Ahn GH, Park HR, Lee SC (2010) Antioxidant and anticancer activities of methanol extracts prepared from different parts of Jangseong Daebong Persimmon (Diospyros kaki cv. Hachiya). J Korean Soc Food Sci Nutr, 39, 500-505 